\title{
New Career Counseling Model: Imperatives for the Universal Basic Education Program in Nigeria
}

\author{
Obi, Osorochi Patricia (Ph.D.) \\ Department of Science Education, College of Agricultural and Science Education, Michael Okpara University \\ of Agriculture, P M B 7267, Umudike, Umuahia, Abia State, Nigeria
}

\begin{abstract}
The current wave of change in the workplace challenges traditional notions of career and career development. This necessitates new ways of thinking about and rendering career counseling services. The critical role of career counseling in the achievement of the objectives of the Universal Basic Education (UBE) program in Nigeria is highly recognized. This is a quantitative study that highlights the need to develop unique and novel approaches to career theory and practice that will give counselors the needed flexibility to render appropriate career guidance to learners in the UBE program in Nigeria. This paper concludes that a new career counseling model is imperative for the successful implementation of the UBE program. It will also enable the learners to find appropriate career path in the $21^{\text {st }}$ century. Implications for career counseling were identified while suggestions for a way forward were proffered.
\end{abstract}

Keywords: Career counseling model, Universal Basic Education, Constructivist Counseling, Traditional career counseling, Nigeria

\section{Introduction}

The Universal Basic Education (UBE) program in Nigeria is a compulsory access to a nine-year basic education launched by the Federal Republic of Nigeria to eradicate illiteracy, ignorance and poverty. It was meant to stimulate and accelerate national development, political consciousness and economic self-reliance. The primary goal of the UBE program is that every learner should acquire appropriate levels of literacy, numeracy, manipulative, communicative and life skills as well as the ethical, moral and civic values needed for laying a solid foundation for scientific and reflective thinking [1].

The basic ingredients of the UBE program is the vocationalization at the post basic level aimed at selfgeneration of employment among others [2]. Some authors [3,4] have identified the central place counseling occupies in the realization of the objectives of the UBE program. The vision of the founding fathers is that at the end of the nine-year continuous, compulsory and free education, every child should acquire appropriate and relevant skills and values and be employable to be able to contribute meaningfully to national development.

The functionality and success of the UBE program in Nigeria will largely depend on the quality and quantity of counseling services the learners receive [3]. The changing face of employment as well as the high rate of unemployment poses serious challenges to career counseling. People cannot be separated from their environments. Human needs and wants are contextual [5]. Peoples' needs and wants change as society changes. What made meaning previously might no longer be relevant or necessary in the present. The individual that is part of the social system is involved in life long career development which is constantly evolving [6].

In view of the changing face of the employment history, there is need to expand career development theories and decision-making models to include the acknowledgement of multiple contextual influences and subjective meanings that clients give to their choice of work and career. If enquiry is limited to only work in jobs and occupations, what might be known about people in the multiple and interacting contexts or environments of their lives is severely truncated. Career theory and practice have thus been challenged to revise and reinvigorate in order to meet the challenges of the $21^{\text {st }}$ century and remain relevant. There is need for revision of career counseling for it to be responsive to the needs of the learners especially at the junior secondary level where solid foundation should be laid for a better future career.

The new career counseling model for the UBE program should be a reflective process of assisting clients in creating self through series of activities taking place in a context of multiple choices from a diversity of options and constraints. This shift moves from emphasizing career choice to empowering clients and improving their decision-making capabilities. The rationale is that if individuals actively participate in the construction of their own life goals, the individuals create their own personal story in relation to their experiences. Through this, a new reality is constructed through dialogue between the client and the counselor. This is referred to as "co-construction" [7]. Career counseling becomes a collaborative process that relies on dialogue between counselor and clients. 
The counseling process shifts from testing and matching to empowering and educating the client to utilize past experiences and current realities to construct future actions. Such past experiences and present meanings will reveal self interests, abilities, achievements and motivations that will lead to self-realization.

The services of career counselor are needed at all levels of the UBE program in Nigeria but become imperative at the junior secondary level. The students need to be properly guided at this transitional stage to choose between expanding their interest in the technical area like woodwork, arts and crafts, mechanics, music and drama, agricultural business or to advance their academic careers by moving into the senior secondary level. To achieve a smooth transition to either side, the counselor needs to properly orientate the students, providing detailed information on the utility of each choice in relation to their future career prospects vis-a-vis the high unemployment rate in the formal sector. They need to be assisted to identify the bountiful opportunities that exist in the informal sector. The acquisition of technical skills helps them to avail themselves of the opportunities that exist in the informal sector.

It has been pointed out [8] that the rapidly changing career situation demands a contemporary approach. It is, therefore, essential for career counselors to take cognizance of the shift and adjust their academic disciplines to accommodate these changes. The modified discipline needs to reflect innovative methods, technologies and structures to ensure effective career counseling [9]. The challenge of the $21^{\text {st }}$ century has been about the capacity to address the complex needs of diverse client groups [10]. In the light of the globalized world where the influence of technology and movement of people, services and fields of study across national borders and across cultures are growing exponentially, there is need for a revision of career counseling for it not only to remain relevant and appropriate, but to serve the growing clientele.

Radical changes in people's lifestyle and career planning as a result of the phenomenal technological advancement and information explosion of the $21^{\text {st }}$ century have brought career counseling practice at a crossroad. New careers requiring new skills emerge and disappear equally quickly [8]. Career counselors need to adopt new ways to respond proactively to the changing scenario.

\subsection{Traditional Career Counseling}

\section{Career Counseling}

Careers have traditionally being defined as the sequence of jobs, roles and positions individuals hold during their working lives [11]. The traditional career counseling process has been viewed as a matching process in which career decisions were based on matching self-knowledge and the world of work. Career counseling has been defined as a composite of all counseling procedures related to the choice of and preparation for a career [12]. These processes include the interest inventories, aptitude and personality tests. In the traditional career counseling model, psychometric tests were used to mirror the individual. This image was then matched with the character traits suited to specific career. If the values, interests and abilities of the individual were considered congruent with the requirements of the specific career, the assumption was made that the individual would find that career stable, productive and satisfying.

The above stance emanate from the theories of career development-Trait and factor theory, [13], sociological approach, [14] and the integrative lifestyle model, [15] to mention a few. The underlying assumptions of these theories are that each individual possesses unique, measurable characteristics; that career demands specific employee character traits; that the individual can be matched to the career and that the more effective the match between the person and the career, the greater the possibility of success. The outcome of the process is thus handed down to the client as a viable career.

The modern career counseling approach should encompass the above. Traditional career assessment techniques can no longer be taken in isolation. The need for alternative approaches to career counseling and career decision making for it to fit the spirit of the age; if the clients are to accept them as useful, has been identified $[16,17,18]$

\section{$1.22^{\text {st }}$ Century Career Counseling}

With the extinction of traditional career concepts of and values of employment, career counselors play vital roles in promoting professional development and adaptation of people to work at every stage of their lives. Career counseling is no longer a single process that is focused on making a job choice. It is a range of interventions to deal with psychological issues that accompany the client's career concerns [19].

The $21^{\text {st }}$ century career can be defined as significant learnings and experiences that identify an individual's professional life, direction, competencies and accomplishments [11]. The world of work has moved away from the era of one-life-one-career perspective, where series of career stages (entrance, establishment, maintenance and retirement) covered the entire person's work life. In its place, a new form of career consisting of series of learning cycles has emerged [11].

The $21^{\text {st }}$ century career counseling is characterized by a turn away from psychometric self toward storied self. This shift is towards self-construction, self-narratives and life-planning [20]. Self as narratives is placed above self as traits. It has been suggested [18] that changes in career counseling redefine the practitioner 
as co-authors and editors of narratives. Instead of diagnosing, assessing and matching, they authorize careers by narrating coherent stories, invest career with meaning by identifying themes and tensions in the storyline and help the clients to learn the skills necessary for the next episode in the story.

At this turning point in career counseling, Savickas [18] identifies the skills and theoretical bases of the post modern career counselor. He proposed Multidimensional approach - psychodynamic, humanistic, cognitive, cognitive-behavioural, constructivist and social constructivist theories. A holistic approach of nurturing the body, mind, spirit and soul is needed in the growing multicultural and multi-pluralistic society. He proposed four important career counseling attributes to meet the challenges of career counseling in the $21^{\text {st }}$ century. They are Concern, Curiosity, Confidence and Control suggesting how a counselor might facilitate their development [18].

Career concern means that an individual has a future orientation and feels invested in thinking about and planning for the future. Appropriate counselor interventions should encourage the client to look ahead to future vocational tasks and transitions. The clients need to know the current situations in the world of work where there are no jobs but with boundless opportunities for work in the informal sector. This fact needs to be hardwired into the psyche of the clients to spur them to seek alternative means of earning a living rather than seeking for employment.

Career curiosity denotes an inquisitive and exploratory attitude with regard to understanding how one's selfidentity fits into the world of work. Career counselors should provide interventions that promote client curiosity. This should include issues about what serves as motivators - extrinsic and intrinsic, encouraging clients to set realistic goals and making concrete plans on how to reach their goals and engaging in exploratory practical activities. This may mean trying their hands on mini money-making ventures like producing and marketing articles from woodwork, arts and crafts, agricultural products to mention a few. This is a practical way of demonstrating the monetary value of their creativity.

Career confidence according to [18] refers to the individual's anticipation of successful outcomes related to their intentional efforts. Counselor's roles in promoting career confidence include encouragement, affirmation of client's strengths and capabilities, role modeling and active involvement in problem solving through simulations.

Career control means empowering individuals to feel capable and responsible for constructing their own careers and not rely on government or business to provide employment for them. Counselor's responses that facilitate and promote client's sense of control include encouragement, affirmation of strengths and modeling of optimism regarding career development outcomes. Counselors can exhibit attitudes that foster creativity and innovativeness in the clients. They should assist the clients to believe in themselves and their ability to weather the storm of global unemployment.

The crucial element of the $21^{\text {st }}$ century is the importance of empowering clients to design their lives that are experienced as satisfactory and that can be redesigned as needs, interests and life experiences change. Career counselors cannot achieve this if they still hold fast to the traditional models of career counseling. Clients should after career counseling be better equipped to confront the complexities of negotiating a career pathway and become motivated to realize specific goals that could stand them on good stead in their career and life development.

\subsection{UBE SCHEME}

The UBE program in Nigeria lays emphasis on the acquisition of practical skills up to the Upper Basic level. This is with a view to boosting the middle level manpower where a noticeable gap has existed. To achieve this laudable objective, the services of career counselors are imperative. Their primary responsibility is to sensitize the clients on the relevance of the skills for future career options in the face of the high unemployment rate in the country. The UBE scheme was established to actualize the objectives the Universal declaration for Education for All (EFA) goals and the Millennium Development Goals (MDGs) by 2015.The basic characteristics of the program are free, full access and compulsory education from Primary to Junior Secondary school; Basic Science and Technology to replace Primary Science while Basic Science replaces Integrated Science at the Upper Basic level.

The new UBE program covers both formal and non formal education covering from 3-5 years Preschool; 6-8 years Junior Primary; 9-11 years Senior Primary and 12-14 years Junior Secondary. It also provides for the rural population; challenged individuals; nomadic population and those in physically isolated settlements. Those in urban slums, adult illiterates, street children and people with special needs- the girl-child, the boy-child and other areas of need are also provided for in the new Ube scheme. Considering the objectives of the Ube scheme and the wide range of clients to be served, career counselors need to reposition themselves to be able to render adequate services.

\subsection{UBE Scheme and career counseling}


The role counselors should play in the successful implementation of the UBE program in Nigeria has been spotlighted $[2,21,3]$. They highlighted that from the point of program development to implementation, the counselors' services are worthwhile and indispensable. They identified the following as some of the counselors' critical functions in the new UBE program:

$>$ Organizing orientation programs for various categories of entrants.

$>$ Teaming up with administrative staff to maximize utilization of resources.

$>$ Sensitizing teachers to use available materials to enrich classroom experience and increasing the practical content of their teaching and reflecting their utility in real life situations.

$>$ Reorientating the students to embrace entrepreneurship (job creation).

$>$ Providing for special needs children.

$>$ Ensuring proper record keeping.

$>$ Providing modern career guidance and counseling for all the learners.

$>$ Educating parents on their responsibilities toward their children.

$>$ Assisting children to resolve their academic, social and personal problems.

$>$ Inculcating discipline and morality into the children.

$>$ Bridging the gap between school and the world of work.

\section{Implications for career counselors}

The current global change in the world of work vis-a-vis the objectives of the UBE program and the role counseling is expected to play have series of implications for career counseling. The successful implementation and sustainability of the UBE program greatly depends on the robustness, flexibility and aptness of career counseling services provided.

For the career counseling profession to remain relevant in the present economic realities, it must intensify efforts to serve a diverse clientele in new settings; translate theory and research into knowledge about the career counseling process that can be used in practice as well as construct new tools that exploit the potential of the information technology. It should increase and improve the training offered by counselor education programs; increase advocacy, expand research to generate new Career counselors and adopt a more modern approach to career counseling. In the new dispensation, constructivist approach to counseling is favored. This will provide clients opportunity to construct their own careers and be able to compete favorably in the globalized marketplace. New and creative ways of career assessment need to be developed. Counselors need to be facilitators rather than experts who do all the thinking and decision-making. They should allow their clients to speak, act, think and choose for themselves. Clients should be led to accept responsibility for their own choices and development [8].

The new roles for career counselors cannot be realized without adequate training and retraining. The knowledge and skills they possess are no longer enough considering the wave of change in the world of work. Career counselors therefore need to update their knowledge and skills to be able to equip the youths adequately to overcome the challenges of the $21^{\text {st }}$ century world of work.

\section{Suggestions}

Considering the current wave of change in the workplace, suggestions for a way forward for career counselors, theorists and researchers alike are necessary. As the organization of work has changed, so too should the predominant method of assisting people to make vocational choices. Career theories reflect the times in which they were constructed [22]. There is need to review the extant theories and revise the methods of career guidance and counseling especially as it affects the UBE program in Nigeria.

In the global economy of the $21^{\text {st }}$ century, self-construction is the way forward for career counseling [23]. There is need not only to revise career counseling programs but to construct a new identity for it. The shift to self-construction and life designing in career counseling is illustrative of the growing influence of constructivist philosophy in the theory and practice of career counseling [24]. This should be the main model of career counseling especially at the Junior Secondary level of the UBE program. The learners at this level need to be guided to construct their own careers based on their life experiences, talents and interests in relation to the changing face of employment. There is need to align thoughts with Dike [4] who suggests the need to properly prepare teachers and counselors in the modern technologies to enable them educate students who would be expected to function effectively in their modern work environments and to compete favorably in the global market place.

There is need to employ more career counselors for the Junior Secondary level. From observations, many of the students at the Junior Secondary schools especially the public schools are not being served. Regrettably, this is the time they need it most. They need to be empowered and encouraged to make important career decisions, to either expand their vocational skills or to pursue academic careers. These are decisions that will affect their future in immeasurable ways. 


\section{Conclusion}

Recent trends in the workplace have challenged career counseling to re-examine and clarify their roles towards assisting individuals to adapt to new demands and carve out a niche for themselves in the $21^{\text {st }}$ century world-of-work. For the UBE program to be successful there is need for career counselors to reposition themselves and review their approaches to career counseling to be able to meet the needs of the clients. Career counselors are enjoined to adopt constructivist approach to counseling utilizing counselor attributes of concern, curiosity, confidence and control. With this the youths will be adequately prepared to earn a living in a world where there are no jobs but with boundless work opportunities for those who have prepared themselves for it. By so doing, they will contribute to the success and sustainability of the UBE program.

\section{References}

[1] E. E. Ebenuwa-Okoh, Counseling environment as predator of guidance practice effectiveness in Universal Basic Education (UBE) Program. Educational Research and Review, 7 (6) 2012, 133-137. Available online at http://www.academicjournals.org/ERR. DOI: 10.5897/ERR10.196.

[2] G. Obioma, Restructuring teacher education in the context of school curriculum reform. The Educational Psychologists. A journal of the Nigerian Council for Educational Psychologists 2(1), 2006, 3-9.

[3] P. Arhedo, I. Adomeh, \& O. Aluede, School Counselor's roles in the implementation of Universal Basic Education (UBE) Scheme in Nigeria. Edo Journal of Counseling 2(1), 2009, 58-66.

[4] V., Dike, Lack of resources threatens UBE: News from Africa, Lagos, 2005, Nigeria. Retrieved on July 1, 2008 from http://newsfromafrica.org/newsfromafrica/articles/art-9114.html

[5] D. Brown, \& L. Brooks, Career Choice and Development $\left(3^{\text {rd }}\right.$ Ed) San Francisco: Jossey-Bass.1996.

[6] W. Patton \& M. McMahon, Career development and systems theory: A new relationship. 1999, Pacific Grove C. A. Brooks/Cole.

[7] V. Askitopoulou, \& E. Kantoglou, Career Counseling in the Postmodern Era: FEDORA Summer University: Modern Times: Counseling Students in the $21^{\text {st }}$ Century. Ioannina 2011, 16-18.

[8] J. G. Maree, \& G. Beck, Using Various approaches in Career Counseling for traditionally disadvantaged (and other) learners: some limitations of a new frontier. South African Journal of Education. 24(1), 2004, 80-87.

[9] J. G. Maree, S. E. Bester, C. Lubbe, \& G. Beck, Postmodern Career to a gifted black youth: A case Study. Gifted Education International 15, 2001, 324-338.

[10] M. McMahon, \& M. Yuen, Career Counseling and Internationalization. Asian Journal of Counseling 16 (2), $2009,91-111$.

[11] M. Coetzee, Career planning in the $21^{\text {st }}$ Century: Strategies for inventing a successful career in a workplace without jobs. Cape Town, Juta and Co Ltd, 2007.

[12] C. Plug,D. A. P. Louw, L. A. Gouws, \& W. F. Meyer, Verclarende en Vertalende siel kundewoordehoek. Johannesburg, Heinemann, 1987

[13] D. Brown, Trait and Factor Theory. In Brown, D. and Brooks, L. (Eds.) Career Choice and Development. San Francisco: JosseyBass, 1990a

[14] C. D. Jacobs, N. H. Van Jaarsveld, \& J. W. Von Mollenderf, Beroeps Voorligting Vir die hoer - en Laerskoil. Pretoria: Konsensus Uitgewers, 1988

[15] G. Mallan, Facing the future. Pretoria. Collegium. 1999

[16] D. Bhuyan, Multiple Career choices. After (10+2) with science, Arts, Commerce and beyond. Pustak Mahal, Delhi, 2007

[17] B. G. Barki, \& B. Mukhopadhyay, Guidance and Counseling: A manual. New Delhi Sterling Publishers Private Limited, 2007

[18] M. L. Savickas, Career counseling in the Postmodern Era. Journal of Cognitive psychotherapy: International Quarterly 7 , $1993,205-215$.

[19] E. L. Herr, Career counseling: A process in process. British Journal of Guidance and Counseling. 25, 1997, 81-93.

[20] V. R. Peavy, Constructivist Career Counseling. Greensboro N. C.: Clearing House on Counseling and Student Services. (ERIC Document Reproduction services, No. ED. 1999, 401-504.

[21] Author, Successful implementation and sustainability of the Universal Basic Education (UBE) Scheme through quality assurance in teacher education. Nigeria Journal of Curriculum studies: A Journal of Curriculum Organization of Nigeria (CON) 15(4) 2008, 113- 121 .

[22] M. B. Watson, \& G. B. Stead, An overview of Career theory. In G. B. Stead and M. B. Watson (Eds.) Career Psychology in the South African Context (2 ${ }^{\text {nd }}$ Ed. 13-34) Pretoria, South Africa. Vanschaik. 2006

[23] M. L. Savickas, Helping people choose jobs: A history of guidance profession. In J. A. Athanagou and R. Van Esbroeck (Eds.) International Handbook of Career Guidance. 2008 (Pp 97-113) Dordrecht, the Netherlands. Springer Science.

[24] M. L. Savickas, L. Nota,J. Rossier,J. Dauwalder, M. E. Duarte, J. Guichard, et al, Life designing: A paradigm for Career Construction in the $21^{\text {st }}$ Century. Journal of Vocational Behaviour .75(3), 2009, 239-250. 